Title "I can feel myself being squeezed and stretched, moulded and grown, and expanded in my capacity to love loudly and profoundly": metaphor and religion in motherhood blogs

\title{
Helen Ringrow
}

\begin{abstract}
This article will explore how metaphors of motherhood are used by contemporary female bloggers who are affiliated with certain faith groups. Within religious contexts especially, motherhood blogs are often seen as suitable activities for women (and for young stay-at-home-mothers in particular). Motherhood blogs, like similar female-oriented texts such as internet parenting forums, have a key role to play in terms of understanding, replicating, and/or challenging gendered norms, both online and off (cf. Mackenzie 2017b, 2018). This article examines two sets of so-called 'mommy bloggers' from North American Church of Jesus Christ of Latter-day Saint and Evangelical Christian backgrounds, following Knapton's (2013) work on metaphor in pro-anorexia blogs. It analyses emergent online representations of motherhood in these two internet communities whose faith groups hold similar (yet not identical) beliefs, which include beliefs about the divine calling and design of being a mother. The analysis of selected extracts from the blogs suggests an explicit foregrounding of religious elements in the Evangelical Christian blogs, whereas the religious context tends to be more subtly expressed or axiomatic for the Latter-day Saint bloggers. Common metaphors of motherhood (such as MOTHERHOOD IS A JOURNEY) appear frequently in the discourse of both digital communities, presenting motherhood as a difficult yet immensely rewarding experience, and one which can be shared with others online.
\end{abstract}

Keywords: metaphor; motherhood; bloggers; religion

\section{Introduction}

This article examines representations of motherhood in what are often called religious 'mommy blogs'. The findings and discussion hope to add to our understanding of how metaphors are used by (those who identify as) women in this religious digital context. Personal mommy bloggers can be seen as creating 'real time' autobiographies and as displaying a certain intimacy by revealing some (although not all) of their carefully 'curated' thoughts and experiences with their readers (Morrison 2010, 2011). In the early days of mommy blogging, there was much praise of these kinds of blogs as alternative representations of motherhood because: "[...] women were talking openly and honestly about the daily drudgery involved in raising children who bring them great 
joy, but at the same time are also very demanding" (Hunter 2016: 1308; see also Petersen 2015: 27). Mommy blogging has been regarded as a "radical act" in that women are able to write publicly about historically and traditionally private aspects of motherhood in their own words and on their own terms (Lopez 2009). However, as mommy blogging (like virtually all other genres of blogging) has become increasingly monetised, there are compelling arguments that this commercialisation is lessening the perception of motherhood blogs as primarily authentic online communities (Orton-Johnson 2017; Hunter 2016) ${ }^{1}$. This article explores two sets of motherhood bloggers from North American Church of Jesus Christ of Latter-day Saint and Evangelical Christian backgrounds, focusing on the use of metaphors to describe the experience of being a mother.

\section{Review of previous literature}

\subsection{Blogs in religious contexts}

Blogs are relatively difficult to define as they vary in scope and nature, but their use tends to create or nourish a social online community (Myers 2010). 'Online community' is a broad term, but Pihlaja (2018: 17-18) suggests it can be useful to think of online community in terms of identifying patterns which indicate a sense of belonging for the individual. Mommy blogs can be further defined in a generic sense as a virtual community of mothers, which (among other aspects) may offer emotional support for the reader (Petersen 2015: 22-24). Petersen (2015) draws together the following components of mommy blogs: substantive elements comprising humour, anger, guilt, fame, the female experience, loss; stylistic elements comprising photos, events, branding, giveaways, ethos, conversational tone; and the organising principles of rebellion (against pre-conceived notions of the 'perfect mother') and community (sharing with and encouraging other mothers in this online context).

North American women who strongly identify with a faith group seem to have found their niche within the so-called 'mamasphere' of religious blogs, as motherhood blogging has gained popularity amongst some Evangelical Christian and Latter-day Saint women, especially young

\footnotetext{
1 So-called 'snark' websites such as Get Off My Internets (GOMI) often critique what they regard as the apparent 'loss of authenticity' of bloggers due to pressures of commercialisation (see Hunter 2016).
} 
wives and stay-at-home-mothers (SAHMs) (cf. Lopez 2009). Blogging appears to be regarded and even encouraged as a positive activity for mothers, as a way to share the highs and lows of parenting with other women amongst and outside their faith communities (Ringrow 2020; Whitehead 2013). The proliferation and popularity of religious mommy blogs may be in part due to the emphasis from Latter-day Saint and Evangelical Christian doctrine and cultural practices on being both a wife and mother. Religious affiliation has historically corresponded to a prioritisation of more conservative gender roles within the home (Hall et al. 2012; Gallagher and Smith 1999). The two faith groups discussed in this article have their differences (and Evangelical Christianity has differing divisions within it), but motherhood is often presented as divine, important work in both traditions. The official Church of Jesus Christ of Latter-day Saints website contains a page on "Women in the church" which outlines the following description of women's role(s):

As a disciple of Jesus Christ, every woman in the Church is given the responsibility to know and defend the divine roles of women, which include that of wife, mother, daughter, sister, aunt, and friend [...] They also have, by divine nature, the greater gift and responsibility for home and children and nurturing there and in other settings ${ }^{2}$.

Note here the emphasis of women as mothers, and their care of the home. The Family Research Council, a US-based Evangelical think tank, provides the following description of family which is based primarily on Biblical interpretation, as the Bible is seen as the central guide for living amongst Evangelicals (see Pihlaja 2014: 50-51):

Marriage and the family were God's idea, and as divine institutions they are not open to human renegotiation or revision [...] In keeping with his wonderful design, the Creator will normally bless a married couple with children, and it is his good plan that a family made up of a father, a mother, and several children witness to his glory and goodness in a world that has rejected the Creator's plan and has fashioned a variety of God-substitutes to fill the void that can properly be filled only by God himself. ${ }^{3}$

2 For more on this, see https://www.churchofjesuschrist.org/study/manual/gospel-topics/women-in-thechurch?lang=eng

3 The full text can be found here: https://www.frc.org/brochure/the-bibles-teaching-on-marriage-andfamily 
As with the Latter-day Saint example, we see again the emphasis on women as (married) mothers. Christian self-help literature also reinforces this idea of women being called to nurture: "[...] caregiving, showing hospitality, discipline, teaching, raising children, serving, and more. Every Christian woman is called to the spiritual motherhood of making disciples of all nations" (Furman 2016: 10). Evangelical Christians often cite what they regard as Biblical evidence for the importance of family and motherhood, notably the "wife of noble character" from the Book of Proverbs (Chapter 31) who is viewed as an ideal for many Evangelical Christian women to strive for (see also Genesis 1:28, 2:22, and 2:24; see also Bartkowski 2001 on evangelical marriages).

The traditional significance of women as mothers in these two faith groups may also be one of the possible explanations for Latter-day Saint and Evangelical Christian women having largerthan-average families in the US: according to Pew research in 2015, Latter-day Saint families had an average of 3.4 children; Evangelical Christian 2.3; these figures can be compared to the national average of 2.1. It may be not overly surprising, then, that these women have comfortably found their corner of the blogosphere, as a place to display and discuss their experiences of motherhood (Whitehead 2013; Petersen 2015). This is not to suggest that mothers who are agnostic or atheist are any less interested in or dedicated to the pursuit of motherhood, but rather to highlight how women from Church of Jesus Christ of Latter-day Saint and Evangelical Christian religious communities may be encouraged to pursue family life as their main goal in ways in which non-religious women might not (cf. Bartkowski 2001). As such, this emphasis could increasingly lead these women to consume and produce blogs and other media which focus on motherhood.

As with other bloggers, religious motherhood bloggers can be regarded to varying degrees as 'microcelebrities' (cf. Jerslev 2016; Marwick 2013) who become famous via the internet and maintain a relationship with their audience by updating them on their daily lives, often in terms of "ordinary" content: what they are wearing; what they are eating; what they are feeding their children; date nights; workout routines; after-school activities; and so on (see also Gamson 2011 on the theme of 'ordinariness' in current North American celebrity culture). The blogs analysed

4 Further information on this research can be found at the following website:

https://www.pewforum.org/2015/05/12/chapter-3-demographic-profiles-of-religious-groups/ 
in this article follow a personal blog format, including sponsored posts with affiliate links (see Hunter 2016 on mommy blogs' increased monetisation) and links to bloggers' other social media accounts (notably Instagram). Faith affiliations tend to be displayed somewhere on the site, although these may not always be overly prominent, especially to the casual reader (including a "we believe/l believe/our faith" section which may link to, for example, the official Church of Jesus Christ of Latter-day Saints website).

\subsection{Metaphor in religious contexts}

This study focuses especially on metaphor because of its role in representing shared beliefs and values of certain groups, including faith groups (cf. Semino 2008: 34). Metaphors are a common feature of 'canonical' religious texts such as the Bible and religious books, and what we might call 'non-canonical' texts such as YouTube videos produced by Evangelical Christians (cf. Charteris-Black 2004; Koller 2017; Pihlaja 2013). Metaphor may be especially relevant for religious literature because the subject matter tends to include that which is unknown or more difficult to fully ascertain (Charteris-Black 2014: 181). Like religious modest fashion blogs (which share some similarities in scope and genre to religious mommy blogs), the blogs discussed in this article can be considered religious texts ' $[. .$.$] in the sense that they are written by women who$ identify with particular faiths and discuss spiritual themes' (Ringrow 2020: 20). As such, these texts form part of what is often called a new 'digital religion' (Whitehead 2013: 917; see also Campbell 2012; Pihlaja 2018). Motherhood blogs have a role to play in terms of the construction or challenging of cultural norms, and scripts around what makes a 'good' mother can be negotiated (cf. Mackenzie 2017b: 309; Orton-Johnson 2017:6). In addition, digital religious texts and communities may also intersect with, and inform, offline religious texts and communities (cf. Pihlaja 2018: 25-26). As Orton-Johnson (2017: 9) argues, motherhood blogs provide an intersection between the public and the private: "Mummy blogs represent a contradictory but important middle ground between structural and cultural representations of motherhood and between interpersonal relationships and individual choice".

\section{Methods}




\subsection{Research rationale and aims}

This study has chosen to focus on religious mommy blogs as these blogs are a rich source of data which can be overlooked as somewhat trivial in nature (cf. Petersen 2015: 9-10). These digital 'feminised' spaces can offer women a different voice and/or representation than much of mainstream media (parenting) discourses (Levine 2015: 4-7; Petersen 2015: 10). This article presents the findings of a discourse analysis of extracts from 3 Latter-day Saint and 3 Evangelical Christian blogs, identifying key metaphors of motherhood (cf. Knapton 2013; Ringrow 2020).

\subsection{Data analysed}

The data in this article is comprised of 60 blog entries: 10 entries each from 3 Latter-day Saint bloggers: Love Taza, Hey Natalie Jean (previously Nat the Fat Rat) and The Daybook Blog, and 10 blog entries each from 3 Evangelical Christian bloggers: The Humbled Homemaker, Momastery and The Purposeful Mom. These blogs have been chosen as a sample of popular North American Latter-day Saint and Evangelical Christian mommy blogs. As such, they can be considered as case studies which give a detailed, heuristic explication of a particular subject area and/or genre (cf. Duff 2018). The blog entries selected for analysis were chosen via an assortment of tags on these blogs ("motherhood", "family", "littles", "babies") as it was expected these entries may discuss motherhood in some depth. Reflective of the religious North American mommy bloggers themselves, the data represents a somewhat narrow demographic: these bloggers often appear to be white, married, middle-class, cis-gendered, and heterosexual (cf. Orton-Johnson 2017; Levine 2015; Ringrow 2020) ${ }^{5}$. Despite this homogeneity, analysing these blogs provides salient opportunities for exploring representations of conventional motherhood practices, and the influence of these blogs goes far beyond their immediate cultural and social groups (Levine 2015:11). In my dataset, two popular bloggers deviate from the usual expectations: Natalie Lovin (Latter-day Saint, Hey Natalie Jean/Nat the Fat Rat) has recently got divorced and publicly expressed her issues with the Church of Jesus Christ of Latter-day Saints; Glennon Doyle Melton (Evangelical Christian, Momastery) divorced her husband and re-married

5 This is a somewhat impressionistic generalisation, based mainly on how the bloggers present themselves and their treatment of topics such as marriage, sexuality, and racial (in)equality. The class dimension is much more tricky to ascertain, but can be roughly guessed based on their discussions of disposable income and background. See Orton-Johnson 2017 and Levine 2015 for more on the typical profile of mommy bloggers. 
a woman. Whether these bloggers conform to faith-based gendered ideals or otherwise, "[..] they seem to recognize that motherhood is messy and contradictory, especially through inflexible social categories, and resist stereotypical representations of their lives, despite very much living the norms [...] Blogging as life writing acknowledges the uniqueness of the individual and her ability to find her own way while engaging in dialogue with others" (Petersen 2015: 26).

\subsection{Research ethics online}

There are important questions of research ethics when analysing any online texts, particularly when many of these texts blur the boundaries of public and private (cf. Mackenzie 2017a). We cannot assume that all participants in online communities and contexts share identical views on privacy (Mackenzie 2017a: 311). In this article, I follow a similar ethical procedure to my previous work on modest fashion blogs (Ringrow 2020): as these blogs are freely and widely available, have a named author (not a pseudonym), and do not require registering to access them, I have reproduced extracts in this article for the purposes of academic discussion. However, many of the bloggers rightly request appropriate referencing to their sites: this has been done in the Appendix, where URLs to all blogs can be found (even for the blogs that do not explicitly state this as a requirement). In the interests of disclosure and the knowledge that every researcher comes to their project with their own background and their own perspectives, I am not presently a mother and I have previously identified as an Evangelical Christian. I try to approach my data as openly as possible, and readers should be aware these issues are often highly sensitive and personal.

In addition to the ethical position and decisions made by the researcher(s), the ethics of the actual blogs themselves have been questioned by both fans and critics. This debate is an incredibly complex one, involving issues of children consenting to featuring on their mothers' blogs (in terms of photographs and/or in terms of being named and discussed); the income generated from the blogs (bloggers' children are sometimes compared to child actors in this respect); and the question of digital memory (as critics of these blogs often remind us, the internet is, apparently, forever). Orton-Johnson (2017: 8) poses the important question: "If blogging is a space in which mothers can resist mainstream narratives of material sacrifice, how do concerns over privacy and rights of deletion for children impact the emancipatory potential of these 
platforms?" It should be noted that many bloggers often defend writing about their children by arguing that their blog is only one very small snippet of their days and by extension, their lives; "[...] essentially admitting that their blogs are carefully curated" (Hunter 2016: 1316).

\subsection{Approaches to the data}

The approach to the data follows the procedure I have used previously for examining religious modest fashion blogs (Ringrow 2020). This article applies Conceptual Metaphor Theory (CMT; Lakoff and Johnson 1980/2003; see also Charteris-Black 2004). A key tenet of CMT is that metaphor is regarded as a mapping between a more accessible domain (source) and one which is trickier to describe (target). Conceptual metaphors are used "[...] because these are domains of abstract knowledge to which we have no real access and consequently need interpreting and repackaging in physical terms" (Giovanelli and Harrison 2018: 22). In this article, I use an adapted version of Knapton's (2013) approach to conceptual metaphor in pro-anorexia blogs (another gendered domain, albeit different contextually to religious mommy blogs). I am dealing with a smaller dataset than Knapton (2013) and, as such, the corpus elements have been omitted. I have analysed my data manually using the following:

1.close reading of data

2.marked and identified metaphorical expressions (using MIP, metaphor identification procedure, from the Pragglejaz Group, which aims to help systematise metaphor classifications. For more on this, please see https://www.lancaster.ac.uk/staff/eiaes/Pragglejaz Group 2007.pdf)

3.metaphorical expressions grouped according to their conceptual metaphors (Ringrow 2020).

I focused primarily on identifying the target domains for MOTHERHOOD. Like virtually all linguistic approaches, CMT has its limitations, especially in terms of (the lack of) transparency in how researchers identify their metaphors (cf. Gibbs 2009). As with my previous research (Ringrow 2020), the use of the steps outlined above is an attempt to provide a clear and systematic overview of how the analysis was conducted. The following sections discuss how metaphors of motherhood are constructed in the religious mommy blogs analysed, understood in light of previous literature on metaphor in religious 
and non-religious contexts (including Charteris-Black 2004; Knapton 2013; Ringrow 2020; Koller 2017) and with reference to the spiritual and digital contexts of these blogs. As this is a relatively small dataset, the emphasis is on qualitative discussions, but the minimum threshold of metaphors occurring 3 times was chosen as a starting point for further discussion (following previous research on metaphors in modest fashion blogs, cf. Ringrow 2020). The following findings and discussion are not necessarily focused on which metaphors are novel, but rather how familiar metaphors have been refashioned to serve particular functions in the context of religious motherhood online.

\section{Findings}

\subsection{Overview of findings}

Common metaphors from my blog sample are discussed in the following sections, and what emerges is a merging of what we might call 'secular' and 'religious' domains (Cameron 2013; Ringrow 2020): conventional, everyday metaphors tend to be repurposed to apply specifically to the experiences of motherhood (the importance of which, for these women, is filtered through the lens of their faiths). In other words, the blogs tend to re-use or reapply metaphors found in other texts, religious and otherwise (cf. Charteris-Black 2004). I use the terms sacred and secular to mean two areas which are often regarded as somehow different, or belonging to different spheres or genres. The 'secular' versus 'religious' distinction does not, however, fully capture the nuances of what is arguably a more messy reality of lived experiences, personal convictions, and legal ethics (cf. Benson 2010). Other religious women, such as Hasidic Jews, challenge this sacred/secular divide by repurposing secular cultural elements for spiritual reasons, and thus merging these two domains for religious benefits (Fader 2009). The sections which follow give examples of metaphors found in the data to describe motherhood, but it is not an exhaustive list (see section 3.4). The metaphors discussed are: MOTHERHOOD/PREGNANCY IS A JOURNEY [TO A DESTINATION OF SPIRITUAL FULFILMENT] (4.2); MOTHERHOOD IS A JOB (4.3); and STAGES OF LIFE ARE SEASONS (4.4).

\subsection{MOTHERHOOD/PREGNANCY IS A JOURNEY [TO A DESTINATION OF}




\section{SPIRITUAL OR EMOTIONAL FULFILMENT]}

In the metaphor MOTHERHOOD IS A JOURNEY [TO A DESTINATION OF SPIRITUAL OR EMOTIONAL FULFILMENT] and the related PREGNANCY IS A JOURNEY [TO A DESTINATION OF SPIRITUAL OR EMOTIONAL FULFILMENT], features from the source domain of JOURNEY are mapped onto the target domains of PREGNANCY and MOTHERHOOD, which may highlight the emotive aspects for the reader:

1. I've never done any of this before and it can all be a bit hard to navigate at times (Love Taza)

2. Whatever trials we are facing as moms, whatever hardships are making us feel hopeless, frustrated and confused, these struggles do not have to define our journey through motherhood. Instead, when we admit that it's hard, that we aren't enjoying it all of the time like we thought we would, we see our need for the cross (The Purposeful Mom)

3. My biggest surprise this pregnancy is just how magical each step remains, even if i've done this thing once or twice before (Love Taza)

4. How do we deal with the uncomfortable feelings associated with being looked down upon by others in our mothering journey? (The Purposeful Mom)

5. You can't miss your boat. It's yours. It stays docked until you're ready. The only boat you can miss is someone else's. Let them have theirs while you wait for the boat God made for you (Momastery)

This use of the JOURNEY source domain is perhaps unsurprising given its extensive documentation as a conventional metaphor used to discuss elements of life in multiple contexts (Lakoff and Johnson 1980/2003; Dancygier and Sweetser 2014: 45). Journey metaphors are especially prevalent in the Bible and other forms of literature written by or for Christians (Charteris-Black 2004: 204; Koller 2017: 10; Ringrow 2020), often to indicate spiritual development or maturity (Charteris-Black 2004: 205-6). Journey metaphors in spiritual contexts tend to encompass the formulae SPIRITUAL LIFE IS A JOURNEY; SPIRITUAL ACTIVITY IS TRAVELLING ALONG A PATH TOWARDS A GOAL; and 
SPIRITUAL LIFE IS A STRUGGLE FOR SALVATION (Charteris-Black 2004). In the examples above, being a mother is seen as a journey which is simultaneously difficult (with obstacles along the way, making it, as in example 1, 'hard to navigate') and rewarding. The journey is presented as being very much worth it, supporting Charteris-Black's (2004: 206-208) identification of the conceptual metaphor formula EFFORT MADE TOWARDS A SPIRITUAL GOAL IS WORTHWHILE. To build on and adapt Giovanelli's (2014; Giovanelli and Harrison 2018: 23) mappings in LIFE IS A JOURNEY to MOTHERHOOD/PREGNANCY IS A JOURNEY [TO A DESTINATION OF SPIRITUAL OR EMOTIONAL FULFILMENT], one can reasonably conceptualise travellers as mothers; the starting point of the journey as pregnancy or giving birth; the end point as death; events and actions experienced as episodes in motherhood; distance travelled as progressing through milestones in your child(ren)'s life; deciding on a route as making parenting choices; and obstacles on the journey as the problems and difficulties of parenting that need to be overcome. In example 5, the reader is advised to wait for the boat which is specifically for them, suggesting that God has carefully placed these mothers in particular situations at particular times.

Thinking more specifically about the journey type, the journey metaphors in the blog extracts are often those of the more generic journey. Occasionally, as in example 5 (you can't miss your boat), the type of journey is identified (cf. Lakoff and Johnson 1980/2003: 44-45), and this enables a more specific extended mapping for this example with God as the captain or the creator of the boat; mothers as passengers; and so on. However, the more common generic use of the unspecified journey suggests that the journey type is arguably not as important as the notion of moving forward itself: demonstrating progress, and sharing this progress with the blog readers. As such, this idea that the journey is shared is key for these bloggers, as their online communities provide opportunities for encouragement and support (Peterson 2015). Pronoun use helps to create the shared nature of the journey (our journey through motherhood; our mothering journey) in addition to the comments feature on the blogs that allow a certain (albeit controlled) level of reader engagement. Religious mommy blogs enable women to connect with others on a similar 'mothering journey': although individual family situations may differ, bloggers and their readers can find shared ground as they travel forward 
together, facing various trials of being a parent along the way.

\subsection{MOTHERHOOD IS A JOB}

The metaphor MOTHERHOOD IS A JOB is used to draw attention to the work of mothering, with MOTHERS ARE BOSSES/CEOS and CHILDREN ARE EMPLOYEES/SUBORDINATES also appearing as part of this conceptual metaphor. Examples from the data include:

1. My hardest job and my proudest accomplishments. My loves, my lights and my whole life, right there, contained in those two little souls. Lucky, lucky me (The Daybook Blog)

2. If I set up a fun Pinterest activity with my boys and start to micromanage, then I probably need to stop and do a heart check (The Humbled Homemaker)

3. Brandon [her husband] goes off to work and i don't feel jealous of his importance or his title. i rather respect his sacrifice all the more, because i had that life once and i hated it. it was not for me. this right here, this is the promotion. and huck's [her son] not the boss, like some might think. i'm the boss. i'm more than the boss (Hey Natalie Jean) ${ }^{6}$

In keeping with the emphasis placed on women's divine calling as a mother outlined in Section 1, this metaphor categorises motherhood as work. These metaphorical expressions can be contextualised with reference to huge cultural debates in North America (and elsewhere) around women working outside of the home, including the classification of stay-at-home-motherhood as a career (note the work of motherhood is arguably not always metaphorical; see Dillaway and Paré 2008 for more on this). Religious bloggers who stay at home may wish to reaffirm their choices and respond to critiques by deliberately stressing the work involved in motherhood, making parallels with paid work. This can be clearly seen in example 3 in which the blogger is identifying herself as the boss, responding to criticism that it is her infant son who in fact seems to be in

6 Lack of capitalisation seems to be a deliberate idiosyncratic choice for this blogger and so the original spelling has been reproduced here. 
charge. She also contrasts her previous career ( $i$ hated it) with her current one as stayat-home mother (this is the promotion). Whether these bloggers have another job in addition to being a mother or not, the metaphor of motherhood as a job highlights the labour of parenting as a worthwhile pursuit.

\subsection{STAGES OF LIFE ARE SEASONS}

In the conceptual metaphor STAGES OF LIFE ARE SEASONS, different time periods of life as a mother are conceptualised as SEASONS. Importantly, some of these seasons are often seen as busy and/or difficult:

1. Seasons come and go in life and there will be different needs based on that particular season we find ourselves in (The Purposeful Mom)

2. How do you grow as a Christian during the busy season of motherhood? This season might be gruelling, Mama (The Humbled Homemaker)

3. You see, when I was living with this season of sickness after sickness and trying to balance motherhood with a toddler and an infant and pregnancy to boot, I thought I was failing as a mother (The Humbled Homemaker)

4. When I started this blog five years ago (has it really been that long?!), I was knee-deep in one of the hardest seasons of my life; I was mothering a toddler and newborn, and I had absolutely no idea what I was doing (The Humbled Homemaker)

In these uses of season, it is not clearly defined when these periods begin and end, although the fact that they will inevitably end is arguably encouraging if this season is particularly "gruelling", as example 2 suggests. The STAGES OF LIFE ARE SEASONS metaphorical expression is not unique to Christianity, but the idea of life (and spiritual life in particular) being compared to seasons seems especially prevalent in contemporary Evangelical discourse, especially in North America. This may be influenced by the Biblical book of Ecclesiastes which provides guidance on dealing with the seasons of one's life; 
in the examples outlined above, the seasons mainly refer specifically to episodes in one's life as a mother. Ecclesiastes is a book about life's purpose and meaning, and explicitly uses the domain of SEASON, for example:

For everything there is a season, and a time for every matter under heaven: a time to be born, and a time to die; a time to plant, and a time to pluck up what is planted; a time to kill, and a time to heal; a time to break down, and a time to build up; a time to weep, and a time to laugh; a time to mourn, and a time to dance (Ecclesiastes 3: 1- 4).

Evangelical Christian self-help literature and Biblical commentaries on the book of Ecclesiastes also make use of this metaphor, with recurrent references to life's seasons: "[...] these inexorable seasons: not only those of the calendar, but that tide of events [...]" (Kidner 1976: 38); "The seasons of life roll by at an astonishing rate" (Swindoll 1983: 17); "It takes years for us to grow to adulthood, and it takes a full season for fruit to mature and ripen" (Warren 2002: 217). In some variations of the season metaphor, we have a more explicit mapping, for example, winter is often seen as a season of reverence (Swindoll 1983) and/or older age (Davies 2008).

The source domain of SEASON shares similarities with another religious metaphor identified by Charteris-Black (2014) in his study of metaphors in the Bible: CIRCUMSTANCES ARE WEATHER. In both STAGES OF LIFE ARE SEASONS and CIRCUMSTANCES ARE WEATHER, events and times in life (and, for the examples discussed here, events and times relating to motherhood particularly) are connected to the natural world. The SEASON metaphor also links to the JOURNEY metaphor in Section 4.2, as mothers often describe their personal journey through the seasons of life and motherhood. This connection between season and journey also appears in the Christian self-help literature, as the following quotation from Swindoll (1983: 435) demonstrates:

How tragic to move through the seasons without realising their ultimate purpose! [...] Are you absolutely certain that you possess His gifts of forgiveness and 
purpose? You can have that assurance if your traveling Companion through the year is the Son of God. He alone can give meaning to the cycle as He enables you to grow strong in all the seasons of your life.

\section{Discussion}

The analysis of blogs in this sample suggest shared, similar metaphor usage amongst Evangelical Christian and Latter-day Saint motherhood bloggers. Metaphorical expressions seem to enable these women to discuss important aspects of their lives, reflecting the power of metaphor to construct and represent values (cf. Semino 2008: 34). As argued earlier, the blogs analysed here can be seen as religious texts, but this does not mean that all the content on the blogs (including the metaphors) is explicitly or even implicitly religious in nature. Like religious modest fashion blogs, religious mommy blogs represent an intersection between what we might view as the secular and the sacred (although, as noted earlier, these domains are not always diametrically opposed). What we often have is a repurposing of common metaphors in these religious contexts, as Dancygier and Sweetser (2014: 209-210) also argue: "One thing which emerges saliently from the study of religious metaphor is how frequently religious language simply applies more general metaphors to the domain of religion". The metaphors themselves may not necessarily be "religious", but they could hold more significance given the divine nature of motherhood for these women. Indeed, these blogs are part of a wider picture in which these bloggers juggle spiritual and secular aspects of their lives, many of which are gendered, grounded in '[...] faiths which emphasise the importance of different roles for men and women within familial and societal contexts' (Ringrow 2020: 31). It is entirely plausible that religious mommy bloggers and non-religious mommy bloggers could both make use of, for example, the JOURNEY metaphor, but it may have a certain spiritual meaning for the former group. Future comparative work could help to identify metaphors which may be unique to religious mommy bloggers (or even the religious mommy blogosphere), although given the prevalence of common and repurposed source domains, it is probably unlikely that many of the metaphors will be truly novel. For the two 
bloggers in this study who have expressed changes in their views and beliefs (Natalie Lovin and Glennon Doyle Melton), further research in this area could explore a possible diachronic shift in their metaphor usage.

Although metaphorical usage appeared to be common and shared across the Latter-day Saint and Evangelical Christian blogs, another finding emerged which suggests a potential difference between the two sets of bloggers. The Evangelical Christian bloggers tended to reference their religion more explicitly than their Latter-day Saint counterparts, either in the metaphor itself or in other related lexical items, including examples such as: we see our need for the cross (The Purposeful Mom); you wait for the boat God made for you (Momastery); and how do you grow as a Christian (The Humbled Homemaker). This pattern suggests a more explicit foregrounding of the religious aspects for the Evangelical Christian bloggers, whereas the Latter-day Saint bloggers make less direct reference to their faiths. For the Latter-day Saint bloggers, the religious context tends to be more subtle or axiomatic; there are occasional references to Heavenly Father (their preferred way of referring to God) especially on special occasions such as weddings, baptisms, Easter, and so on. For the Evangelical Christian bloggers, their faith has more of a constant explicit narrative presence on their blogs, where they continually reference God, Jesus, their Saviour, growing as a Christian, challenges they face as a Christian, and so on. In recent North American history, members of the Church of Jesus Christ of Latter-day Saints have arguably been subject to misconceptions and hostility (Haws 2013), so it is not unlikely that this may have some kind of (even tangential) effect on how these bloggers wish to represent their faith (perhaps a little cautiously). The Evangelical Christian bloggers seemed to make more reference to the SEASON domain which, as suggested earlier in 4.4, appears to be part of common Evangelical Christian discourse, even if it does not necessarily seem to be an overly religious metaphor at first glance. Future research on a larger dataset could help to investigate - and quantify - these patterns in more detail.

\section{Conclusion}

This article has identified how metaphors are used in a selection of contemporary religious 
motherhood blogs, making connections between gender and faith in this online context. Of course, not all Evangelical Christian and Latter-day Saint women will write and consume this kind of blog content, and those who do may consume it critically. Religious identity is complex and scholars researching this area should be careful to consider their own assumptions about certain 'categories of belonging' and the connotations of these (cf. Power's 2015 work on rural Latter-day Saint women's self-identification). Follow-up reader response work could consider the (intended and otherwise) audience's positions on the blog themes and content, including to what extent they recognise the metaphors. Metaphor identification is not always straightforward, especially if the writer and the audience share different belief systems, as Charteris-Black (2014: 176) outlines: "[...] believers and non-believers will differ in the extent to which they perceive language in religious contexts as metaphoric. For the believer, there will be greater tension between semantic fields than for the non-believer who will tend towards a literal interpretation".

The source domains identified in this article of JOURNEY, JOB, and SEASON help to describe these bloggers' experiences of parenthood. The metaphors themselves may not appear to be uniquely religious, but, as argued throughout this article, their use should be placed in the context of faiths which emphasise women's role as a mother. This emphasis is not unproblematic, especially in changing societal contexts in North America (cf. Mcquillan et al 2008). The emphasis on being a mother as opposed to a parent paints a picture of a gendered form of parenting in which mothers may still be seen as the dominant caregiver, even if this is not always the case (cf. Sunderland's 2006 work on parenting magazines). These bloggers negotiate their roles as individual mothers and as members of a collective online community of motherhood bloggers. They emphasise motherhood as continually worthwhile, if difficult, which may further lead to the taboo of challenging the idea that motherhood is always worthwhile. The metaphors in this article form part of a broader discourse of religious mommy blogs which presents motherhood as a difficult yet immensely rewarding experience: one which can be shared with others online, and one which is not without its challenges. 


\section{References}

BARTKOWSKI, J. P. (2001). Remaking the godly marriage: Gender negotiation in evangelical families. New Brunswick, NJ: Rutgers University Press

BENSON, I (2000). 'Notes towards a (re)definition of the 'secular." University of British Columbia Law Review, 33, pp. 520-881.

BOWLER, K. (2019) The Preacher's Wife: The Precarious Power of Evangelical Women Celebrities. Princeton: Princeton University Press.

CAMPBELL, H. (2012) Digital Religion: Understanding Religious Practice in New Media Worlds. London: Routledge.

CAMERON, J. (2013) 'Sartorially Sacred or Fashion Faux Pas: Visual Interpretations of Modesty Online' in Abby Day, Giselle Vincett and Christopher R. Cotter (eds). Social Identities Between the Sacred and the Secular. Farnham: Ashgate.

CHARTERIS-BLACK, J. (2014) Analysing Political Speeches: Rhetoric, Discourse and Metaphor. Basingstoke: Palgrave Macmillan.

CHARTERIS-BLACK, J. (2004) Corpus Approaches to Critical Metaphor Analysis. Basingstoke: Palgrave Macmillan.

DANCYGIER, B. \& SWEETSER, E. (2014) Figurative Language. Cambridge: Cambridge University Press.

DAVIES, J. (2008) 'A Practical Theology of Aging: Biblical Perspectives for Individuals and the Church'. Christian Education Journal 5(2), pp. 274-239. https://doi.org/10.1177/073989130800500203 
DILLAWAY, H., \& PARÉ, E. (2008). 'Locating Mothers: How Cultural Debates About Stayat-Home Versus Working Mothers Define Women and Home'. Journal of Family Issues, 29(4), pp. 437-464. https://doi.org/10.1177/0192513X07310309

DUFF, P. (2018) 'Case Study Research in Applied Linguistics'. In Lia Litosseliti (ed.) Research Methods in Linguistics. Second Edition. London: Bloomsbury, pp. 305-330.

FADER, A. (2009) Mitzvah Girls: Bringing Up the Next Generation of Hasidic Jews in Brooklyn. Princeton: Princeton University Press.

FURMAN, G. (2016) Missional Motherhood: The Everyday Ministry of Motherhood in the Grand Plan of God. Wheaton: Crossway.

GALLAGHER, S. K., \& SMITH, C. (1999). 'Symbolic traditionalism and pragmatic egalitarianism: Contemporary evangelicals, families, and gender.' Gender \& Society, 13, pp. 211-233.

GAMSON, J. (2011) 'The Unwatched Life Is Not Worth Living: The Elevation of the Ordinary in Celebrity Culture'. Publications of the Modern Languages Association of America, 126(4), pp. 1061-1069.

https://www.mlajournals.org/doi/abs/10.1632/pmla.2011.126.4.1061

GIBBS, R. (2009) 'Why Do Some People Dislike Conceptual Metaphor Theory?'

Cognitive Semiotics, 5(1-2), pp. 14-36. https://doi.org/10.1515/cogsem.2013.5.12.14

GIOVANELLI, M. (2014) Teaching Grammar, Structure and Meaning. London:

Routledge.

GIOVANELLI, M. \& HARRISON, C. (2018) Cognitive Grammar in Stylistics: A Practical Guide. London: Bloomsbury. 
HALL, M. E. L., OATES, K. L. M., ANDERSON, T. L., \& WILLINGHAM, M. M. (2012). 'Calling and conflict: The sanctification of work in working mothers'. Psychology of Religion and Spirituality, 4(1), pp. 71-83. https://doi.org/10.1037/a0023191

HAWS, J.B. (2013) The Mormon Image in the American Mind: Fifty Years of Public Perception. New York: Oxford University Press.

HUNTER, A. (2016) 'Monetizing the mommy: mommy blogs and the audience commodity'. Information, Communication \& Society, 19(9), pp. 1306-1320. https://www.tandfonline.com/doi/abs/10.1080/1369118X.2016.1187642?journalCode $=$ rics20

JERSLEV, A. (2016) 'In The Time of Microcelebrity: Celebrification and the YouTuber Zoella'. International Journal of Communication 10, pp. 5233 - 5251.

https://ijoc.org/index.php/ijoc/article/view/5078

KIDNER, D. (1976) The Messages of Ecclesiastes: a Time to Mourn, and a Time to Dance. Downers Grove: InterVarsity Press.

KNAPTON, O. (2013) 'Pro-anorexia: Extensions of ingrained concepts'. Discourse \& Society 24(4), pp. 461-477.

https://journals.sagepub.com/doi/full/10.1177/0957926513482067

KOLLER, V. (2017) 'The light within: metaphor consistency in Quaker pamphlets, 16592010'. Metaphor and the Social World. 7(1), pp. 5-25. https://benjamins.com/catalog/msw.7.1.02kol

LAKOFF, G, \& JOHNSON, M (1980) Metaphors We Live By. First Edition. Chicago: University of Chicago Press.

LAKOFF, G. and JOHNSON, M. (2003) Metaphors We Live By. Second Edition. 
Chicago: University of Chicago Press.

LEVINE, E. (2015) 'Introduction: Feminized Popular Culture in the Early Twenty-first Century'. In Elana Levine (ed.) Cupcakes, Pinterest, and Ladyporn: Feminized Popular Culture in the Early Twenty-First Century. Illinois: University of Illinois Press, pp. 1-12.

LOPEZ, L. K. (2009) 'The radical act of 'mommy blogging': Redefining motherhood through the blogosphere'. New Media \& Society. 11(5), pp. 729-747. https://journals.sagepub.com/doi/10.1177/1461444809105349

MACKENZIE, J. (2017a) 'Identifying informational norms in Mumsnet Talk: A reflexivelinguistic approach to internet research ethics'. Applied Linguistics Review. 8(2-3), pp. 293-314. https://doi.org/10.1515/applirev-2016-1042

MACKENZIE, J. (2017b) '“Can we have a child exchange?' Constructing and subverting the 'good mother' through play in Mumsnet Talk". Discourse \& Society 28(3), pp. 296312. https://journals.sagepub.com/doi/full/10.1177/0957926516687417

MACKENZIE, J. (2018). “Good mums don't, apparently, wear make-up': negotiating discourses of gendered parenthood in Mumsnet Talk'. Gender and Language, 12(1), pp. 114-135. https://doi.org/10.1558/genl.31062

MARWICK, A. (2013). Status update: Celebrity, publicity and branding in the social media age. New Haven, CT: Yale University Press.

MCQUILLAN, J., GREILI, A. L., SHREFFLER, K. M., \& TICHENOR, V. (2008). 'The Importance of Motherhood Among Women in the Contemporary United States'. Gender \& Society, 22(4), pp. 477-496. https://doi.org/10.1177/0891243208319359

MORRISON, A. (2010) 'Autobiography in real time: A genre analysis of personal mommy blogging'. Cyberpsychology: Journal of Psychosocial Research on Cyberspace 4(2). 
https://cyberpsychology.eu/article/view/4239/3285

MORRISON, A. (2011) "'Suffused by Feeling and Affect': the Intimate Public of Personal Mommy Blogging." Biography, 34(1), pp. 37-55. https://muse.jhu.edu/article/447975

MYERS, G. (2010) The Discourse of Blogs and Wikis. London: Continuum.

ORTON-JOHNSON, K. (2017) 'Mummy Blogs and Representations of Motherhood: "Bad Mummies" and Their Readers'. Social Media + Society, pp.1-10. https://doi.org/10.1177/2056305117707186

PETERSEN, E. (2015) 'Mommy Bloggers as Rebels and Community Builders'. Journal of the Motherhood Initiative for Research and Community Involvement 6(1), pp. 9-30. https://jarm.journals.yorku.ca/index.php/jarm/article/view/40238

PIHLAJA, S. (2013) 'It's all red ink': The interpretation of biblical metaphor among Evangelical Christian YouTube users'. Language and Literature 22(2), pp.103-117. https://doi.org/10.1177/0963947013483996

PIHLAJA, S. (2014) Antagonism on YouTube: Metaphor in Online Discourse. London: Bloomsbury.

PIHLAJA, S. (2018) Religious Talk Online. Cambridge: Cambridge University Press.

POWER, K. (2015). 'Charity Chicks: A discourse-analytic study of religious selfidentifications by rural Canadian Mormon women'. In B. R. Lee, \& T. Tak-ling Woo (eds.) Canadian women shaping diasporic religious identities. Waterloo: Wilfrid Laurier University Press, pp. 139-194.

RINGROW, H. (2020) 'Beautiful masterpieces': Metaphors of the female body in modest fashion blogs'. In Helen Ringrow and Stephen Pihlaja (eds). Contemporary Media Stylistics. 
London: Bloomsbury, pp. 15-34.

RINGROW, H. (2016) The Language of Cosmetics Advertising. London: Palgrave Macmillan.

SEMINO, E. (2008) Metaphor in Discourse. Cambridge: Cambridge University Press.

SUNDERLAND, J. (2006). "Parenting' or 'mothering'? The case of modern childcare magazines'. Discourse \& Society, 17(4), pp. 503-528.

https://doi.org/10.1177/0957926506063126

SWINDOLL, C. (1983) Growing Strong in the Seasons of Life. Michigan: Zondervan.

WARREN, R. (2002) The Purpose Driven Life. Michigan: Zondervan.

WHITEHEAD, D. (2013) 'When religious 'mommy bloggers' met 'mommy porn':

Evangelical Christian and Mormon women's responses to Fifty Shades'. Sexualities 16(8), pp. 915-931. https://doi.org/10.1177/1363460713508904

\section{Appendix: list of blogs analysed}

Love Taza http://lovetaza.com

Hey Natalie Jean/Nat the Fat Rat http://heynataliejean.com

The Daybook Blog http://thedaybookblog.com

The Humbled Homemaker http://thehumbledhomemaker.com/

Momastery http://momastery.com/blog/

The Purposeful Mom http://thepurposefulmom.com/ 